\title{
COMPETÊNCIAS DIGITAIS NO ENSINO REMOTO: NOVOS DESAFIOS PARA FORMAÇÃO DOCENTE
}

\author{
Digital Competences in Remote Education: New challenges for Teacher Training
}

\author{
Leticia Rocha Machado ${ }^{1}$ \\ Simone Meister Sommer Bilessimo² \\ Juarez Bento da Silva ${ }^{3}$
}

\begin{abstract}
Resumo: O objetivo da pesquisa é identificar as competências digitais (CD) necessárias para alunos do ensino remoto emergencial (ERE) Brasileiro e discutir as necessidades na formação continuada dos professores. A pesquisa teve uma abordagem qualitativa interpretativa de natureza aplicada, sendo exploratória quanto aos objetivos e como procedimento foi utilizado estudo de caso. Para a coleta de dados utilizou dados de um curso de extensão na modalidade Educação a Distância ofertado em uma Universidade. A coleta ocorreu por meio de uma atividade "Tarefa" de Ambiente Virtual de Aprendizagem (AVA), sendo indagados quais os conhecimentos, habilidades e atitudes necessários para os alunos do ERE. Assim, participaram da pesquisa 29 professores que atuam com diferentes públicos e modalidade de ensino, que estão oferecendo, ou irão ofertar, aulas no ERE. Os dados apresentam 10 CD para o ERE, sendo
\end{abstract}

\footnotetext{
${ }^{1}$ Possui graduação em Pedagogia Multimeios e Informática Educativa pela Pontifícia Universidade Católica do Rio Grande do Sul (2005), Mestrado em Gerontologia Biomédica pela Pontifícia Universidade Católica do Rio Grande do Sul (2007), Doutorado em Informática na Educação pela Universidade Federal do Rio Grande do Sul (2013) e Doutorado em Educação pela Universidade Federal do Rio Grande do Sul (2019). É professora da Faculdade de Educação da Universidade Federal do Rio Grande do Sul. É pesquisadora atuante em três grupos de pesquisa: Núcleo de Tecnologia Digital Aplicada à Educação (NUTED/UFRGS), Laboratórios de Experimentação Remota (RExLab/UFSC) e Educação e Envelhecimento: múltiplas interfaces (UFRGS). ORCID: https://orcid.org/0000-0003-4102-2225 E-mail: leticiarmachado@gmail.com

2 Possui graduação em Engenharia de Produção Mecânica pela Universidade Federal de Santa Catarina (1997), mestrado (1999) e doutorado (2007) em Engenharia de Produção pela Universidade Federal de Santa Catarina. Atualmente é professora com dedicação exclusiva (Professora Associado I) da Universidade Federal de Santa Catarina - Campus Araranguá, inclusive como docente no Programa de Pós-graduação em Tecnologias da Informação e Comunicação. Tem atuado principalmente nos seguintes temas: empreendedorismo, gestão da inovação, integração da tecnologia na educação, bem como o uso das Tecnologias da Informação e Comunicação na educação e em negócios digitais. Experiência com organização de eventos. Participa do Grupo de Pesquisa RExLab - Laboratório de Experimentação Remota. ORCID: https://orcid.org/0000-0002-3326-8703 E-mail: simone.bilessimo@gmail.com

3 Possui graduação em Administração de Empresas pela Pontifícia Universidade Católica do Rio Grande do Sul (1991), mestrado em Ciências da Computação pela Universidade Federal de Santa Catarina (2002), doutorado em Engenharia e Gestão do Conhecimento pela Universidade Federal de Santa Catarina (2007) e pós-doutorado pelo Instituto Superior de Engenharia do Porto (Portugal). Atualmente é professor associado II da Universidade Federal de Santa Catarina, atuando nos cursos de Bacharelado em Tecnologias da Informação e Comunicação e no Programa de Pós-Graduação em Tecnologias da Informação e Comunicação. Também é coordenador do grupo de pesquisas Laboratório de Experimentação Remota (RExLab). ORCID: https://orcid.org/0000-0002-5604-0576 Email: juarezbs.silva@gmail.com
} 
que estas foram apontadas pelos docentes como importantes na modalidade. No Ensino Fundamental II e Médio foram identificadas 3: Utilização básica do computador (desktop) e/ou dispositivo móvel; Letramento Digital; Comunicação através de videoconferência. Já no Ensino Técnico foram identificadas 2: Utilização de AVA; Comunicação através de videoconferência. E, por último, no Ensino Superior, foram identificadas 5 CD: Utilização básica do computador (desktop) e/ou dispositivo móvel; Utilização de AVA; Comunicação através de videoconferência; Cooperação; Produção de material digital. Os dados apontam uma preocupação dos professores referente ao uso básico das tecnologias digitais e, principalmente, utilização qualificada e crítica para que os alunos se tornem produtores e protagonistas do processo de aprendizagem remota.

Palavras-chave: Ensino Remoto Emergencial. Competências Digitais. COVID-19. Formação continuada de professores.

\begin{abstract}
The objective of the research is to identify the digital competences (DC) necessary for students of remote emergency education (REE) in Brazil and to discuss the needs in the continuing education of teachers. The research had an interpretive qualitative approach of applied nature, being exploratory as to the objectives and as a procedure a case study was used. For data collection, data from an extension course in the Distance Education modality offered at a University was used. The collection took place through a "Task" activity of the Virtual Learning Environment (VLE) in which the knowledge, skills and attitudes needed by the REE students were asked. Thus, 29 teachers who work with different audiences and teaching modality participated in the survey, in which they are offering, or will offer, classes at the REE. The data have $10 \mathrm{DC}$ for the REE, and these were identified by the professors as important in the modality. In Elementary School II and High School were identified 3: Basic use of computer (desktop) and/or mobile device; Digital Literacy; Communication via videoconference. In Technical Education, we identified 2: Use of VLE; Communication via videoconference. And, finally, in Higher Education, 5 DC were identified: Basic use of computer (desktop) and/or mobile device; Use of VLE; Communication via videoconference; Cooperation; Production of digital material. The data show a concern of teachers regarding the basic use of digital technologies and, mainly, qualified and critical use so that students become producers and protagonists of the remote learning process.
\end{abstract}

Keywords: Emergency Remote Learning. Digital Skills. COVID-19. Continuing Teacher Education.

\title{
1 Introdução
}

O Brasil foi marcado por uma pandemia do novo Coronavírus (COVID-19), que se alastrou e provocou mudanças significativas nos setores econômico, social e educacional no ano de 2020. A necessidade de manter distanciamento social, ou seja, medidas adotadas para evitar o estabelecimento de interações sociais presenciais da população a fim de evitar a propagação do vírus, surtou mudanças drásticas das relações humanas, em especial na área educacional.

A educação não estava preparada para o distanciamento social em diferentes esferas, muito menos em práticas pedagógicas que permitissem os alunos, desde a Educação Básica até Ensino Superior, a utilizar as tecnologias digitais (TD), principalmente para dar continuidade ao processo de ensino e viabilizar meios para que a aprendizagem pudesse ser continuada. 
Assim, nesse cenário confuso e imerso na necessidade de um cuidado maior na saúde, surgiu o ensino remoto emergencial (ERE). '

No ERE são apresentadas "[...] soluções temporárias de educação completamente remota e/ou híbrida para situações originalmente presenciais, com possível retorno ao formato inicial após o período agudo da crise" (HENRIQUE, BARROS, 2020, p.294). Portanto, com o ERE está incluído também o desafio sobre quais tecnologias e metodologias podem ser utilizadas, como aplicar estratégias pedagógicas que viabilizassem o engajamento e evitar a evasão, assim como a adaptação dos alunos a essa nova prática de aprendizagem. Moreira, Henriques e Barros (2020, p.352) denotam que no ERE as “[...] tecnologias foram e estão sendo utilizadas numa perspectiva meramente instrumental, reduzindo as metodologias e as práticas a um ensino apenas transmissivo".

Nesse sentido, repensar as competências digitais (CD) necessárias para um novo perfil de aluno que participa do ensino remoto emergencial se torna pertinente, uma vez que é preciso compreender não apenas os conhecimentos e as habilidades mais importantes para o ERE, mas também as atitudes necessárias para contexto de ensino. As competências digitais podem ser definidas como um conjunto de conhecimentos, habilidades e atitudes (CHA), que mobilizadas, com o apoio das tecnologias de informação e comunicação, auxiliam o sujeito a resolver determinada situação-problema apresentada (FERRARI, 2012; SILVA, 2018).

As CD são muito discutidas no contexto presencial ou na modalidade a distância (Educação a Distância), especialmente no Ensino Superior e Pós-Graduação. Na Educação Básica, apesar de haver poucos estudos, também são abordadas as práticas pedagógicas viáveis para a sua construção, principalmente no que diz respeito à inclusão digital e sua integração em aula.

A UNESCO cita a necessidade de construir competências na escola, como buscar e filtrar a informação disponível na internet, possibilidade de colaborar e desenvolver práticas que propiciam a autoria. Essas e outras CD devem ser trabalhadas nas instituições de ensino (PEDRÓ, 2016). Mas, considerando o ERE, ou seja, uma educação através das TD e de forma remota e distante, a construção de CD se torna um desafio maior para os professores por não haver estudos científicos publicados ainda sobre a temática, além da falta de capacitação dos docentes para o uso eficaz das tecnologias em sala de aula. Desta forma, a presente investigação tem por objetivo identificar as competências digitais necessárias para alunos do ensino remoto emergencial brasileiro e discutir as necessidades na capacitação dos docentes.

Assim, a partir dos resultados será possível repensar nas formações continuadas de professores para que estes possam planejar práticas pedagógicas condizentes com a realidade desse novo perfil de aluno. O contexto do Brasil foi determinado no intuito de considerar as especificidades dos estudantes no país, assim como abranger os desafios econômicos e a dificuldade de acesso às tecnologias que a população normalmente enfrenta.

Nesse sentido, no intuito de apresentar os principais resultados e discussão sobre a temática, o artigo é dividido em seis seções. Na primeira seção é apresentada a introdução sobre as principais temáticas tratadas no decorrer do artigo. Já a segunda é voltada para retratar o panorama atual do ensino remoto, bem como os desafios para os docentes. A terceira seção, destinada a abordar as competências digitais, trata sobre os conceitos envolvidos. Na metodologia, nesta quarta seção, é apresentada a abordagem da pesquisa, assim como a amostra e etapas de desenvolvimento. Os resultados são apontados na quinta seção, na qual são discutidos os dados coletados, assim como apontamentos realizados pelos participantes da pesquisa. A última seção apresenta as considerações finais do artigo, retomando os principais achados da investigação e sua possível contribuição. 


\section{Ensino Remoto Emergencial e os desafios para os docentes}

O ensino remoto emergencial (ERE) surgiu como uma nova prática na educação, oriundo de um contexto pandêmico que iniciou no ano de 2019 e aumentou em 2020. Assim, com o cenário formado na sociedade, no qual o distanciamento social é necessário para evitar a propagação do vírus COVID-19, novas indagações surgiram, principalmente na educação, que buscou alternativas para dar continuidade às aulas e não prejudicar a aprendizagem dos alunos de diferentes áreas e modalidades. Nesse sentido, muitas dificuldades emergiram, principalmente no que diz respeito ao uso das tecnologias digitais, práticas pedagógicas e estratégias de ação que pudessem viabilizar, parcialmente, a continuidade nas aulas pelos docentes.

Para Bao (2020), devido ao surgimento repentino do COVID-19, a maioria dos professores está enfrentando muitas dificuldades pela falta de experiência nessa modalidade, principalmente no uso das tecnologias digitais para o atendimento dos seus alunos de forma online. Além disso, Saraiva et al. (2020) destacam que a necessidade de atender os alunos de como agir e quais tecnologias utilizar, além de terem que buscar qualificação para usar as TD. Para maximizar o problema, "nem escolas, nem redes de ensino, conseguiram, em um primeiro momento, desenvolver planejamentos abrangentes e produzir orientações claras sobre como os docentes deveriam proceder" (SARAIVA, 2020, p.17).

O ensino remoto emergencial pode ser compreendido como "[...] um formato de escolarização mediado por tecnologia, mantidas as condições de distanciamento professor e aluno" (MORAIS et al, 2020, p.5). Assim, no ERE os professores transpuseram práticas pedagógicas adotadas no modelo presencial para o virtual, utilizando as tecnologias digitais como mecanismo de compartilhamento e interação, como é o caso das videoconferências através das ferramentas Google Meet, Zoom, Google Hangouts ou mesmo plataformas como Google Classroom, Moodle, dentre outras. No entanto, é pertinente ressaltar que o ERE não pode se tornar uma modalidade permanente na educação. Assim como o seu nome diz, ele é "emergencial" e, portanto, é necessária uma transição para uma educação híbrida ou a distância, pois, como frisam Moreira, Henriques e Barros (2020, p.352), é “[...] urgente e necessário transitar deste ensino remoto de emergência, importante numa primeira fase, para uma educação digital em rede de qualidade".

Portanto, essa transição não ocorreu de forma fácil para muitos professores, já que poucos utilizavam TD em suas aulas presenciais, principalmente na Educação Básica no Brasil. Assim, é cada vez mais pertinente discorrer sobre o desenvolvimento de formações que viabilizem o uso adequado, colaborativo e eficaz das tecnologias digitais nas práticas pedagógicas e, principalmente, uma transformação no formato das aulas para contemplar todas as características do ensino híbrido, on-line ou da Educação a Distância. Cabe salientar que a $\mathrm{EaD}$ é distinta do ERE, já que "O ensino remoto permite o uso de plataformas já disponíveis e abertas para outros fins, que não sejam estritamente os educacionais, assim como a inserção de ferramentas auxiliares e a introdução de práticas inovadoras" (GARCIA et al, 2020, p.5).

No entanto, apesar de possuir diferenças da EaD, o ERE precisa ser organizado e planejado, não podendo ser principiante, já que está vinculado à uma base educacional. Moreira, Henriques e Barros (2020, p.353) citam alguns tópicos importantes para o ERE: defina o cronograma das atividades; configure o ambiente virtual por semanas ou tópicos; defina o período para o desenvolvimento de cada atividade; selecione os recursos mais adequados para a execução de cada aula; disponibilize sessões síncronas e assíncronas e com momentos para a avaliação. Bao (2020) ainda salienta alguns aspectos que devem ser considerados na ERE, apontando a importância do papel do professor nesse processo: 
a) Fazer planos de preparação para emergências para problemas inesperados: para evitar questões de problemas de conectividade ou sobrecarga de capacidade nos aparelhos utilizados no ERE, é necessário criar plano "A" e "B" para que o professor faça os ajustes adequados para dar continuidade às aulas.

b) Dividir o conteúdo de ensino em unidades menores para ajudar os alunos a se concentrarem: o professor deve dividir o conteúdo do ensino em sala de aula em diferentes tópicos e adotar um método de ensino modular, sendo necessário em torno de 20-25min por módulo.

c) Enfatizar o uso da "voz" no ensino: no ERE não é possível ver as expressões corporais ou reações emocionais dos estudantes como em uma aula presencial. Portanto, é necessário fomentar que os estudantes participem mais ativamente através das videoconferências, tanto oralmente como textualmente.

d) Trabalhar com professores assistentes (tutores) e obter suporte on-line: os requisitos técnicos do ensino on-line são muito maiores do que o tradicional para professores inexperientes. Assim, o apoio de professores assistentes, ou tutores, é particularmente importante, já que eles podem fornecer consultas e responder perguntas para alunos despreparados para o uso das TD envolvidas.

e) Proporciona subsídios para a aprendizagem ativa dos alunos: o professor deve usar vários métodos para modificar moderadamente as atividades realizadas em casa pelos alunos para fortalecer a aprendizagem ativa dos alunos fora da sala de aula.

f) Combinar aprendizagem on-line e autoaprendizagem off-line de forma eficaz: o professor deve considerar duas fases de ensino: de autoaprendizagem off-line e a de ensino on-line. Na autoaprendizagem off-line os alunos são obrigados a ler a literatura específica da aula e enviar materiais curtos com base em sua leitura dos principais conteúdos da aula. $\mathrm{O}$ docente deve fornecer feedback às tarefas dos alunos e conhecer os níveis cognitivos de aprendizagem. O professor pode fazer ajustes no conteúdo do ensino antes da aula. Na fase de ensino on-line, o docente deve usar uma seção de discussão para que os alunos troquem sua compreensão com base em suas leituras.

Portanto, é cada vez mais necessário no ERE que o professor viabilize estratégias pedagógicas e mecanismos eficazes nas práticas pedagógicas que proporcionem ao estudante, em um contexto caótico e estressante, serenidade para construir os conhecimentos delineados anteriormente. Assim, repensar sobre as competências digitais necessárias para esse aluno é primordial, uma vez que, considerando os conhecimentos, habilidades e atitudes deles, fica mais fácil planejar aulas com base nas especificidades necessárias para o ERE. Desta forma, a seguir é apresentado o conceito de competências, bem como as que estão vinculadas às tecnologias.

\section{Competências Digitais na Educação}

O termo competência vem, ao longo dos anos, sofrendo modificações oriundas das transformações sociais advindas das novas formas de se comunicar, trabalhar e se relacionar. No século XV, a palavra esteve associada com a legitimidade jurídica de pessoas e/ou instituições. Ao longo do tempo, outros campos de atuação começaram a incluí-la, como foi o caso da educação. As novas discussões possibilitaram uma visão diferenciada e utilização que considerassem não apenas como instrumento avaliativo, mas também de construção e/ou aprimoramento de conhecimentos, habilidades e atitudes. Portanto, "A complexidade da questão da competência cresceu em extensão nesta realidade: surgiram critérios de 
competências, categorias de saberes, conceitos particulares que geraram terminologias associadas às competências [...]" (MARINHO-ARAUJO, RABELO, 2015, p.02).

A educação já adotou o termo e sua definição, tanto nos projetos políticos pedagógicos das escolas, como em políticas públicas como, por exemplo, os Referenciais de Qualidade para a Educação Superior a Distância (BRASIL, 2003) e os Parâmetros Curriculares Nacionais (BRASIL, 1998) e recentemente a Base Nacional Comum Curricular (BNCC) (BRASIL, 2018). A Organização das Nações Unidas para Educação, Ciência e Cultura (UNESCO) foi um dos primeiros órgãos a discutir e desenvolver documentos norteadores sobre a certificação e aplicação de competências nos diferentes setores da educação. Atualmente existem muitas publicações e definições de competências sendo utilizadas por autores.

Conforme Küller e Rodrigo (2013, p.39), "Competência é uma palavra polissêmica. Uma das razões da variabilidade de seus significados é a diversidade dos contextos e dos campos de conhecimento em que ela é usada". Philippe Perrenoud foi um dos primeiros autores que iniciaram os estudos na educação em 1999. Ele trouxe novos elementos ao conceito, que antes era associado apenas com o conhecimento e, atualmente, está relacionado com outros "saberes".

Portanto, uma nova proposta é apresentada ao conceito, que provém da necessidade de diferenciar a competência de capacidade ou mesmo de conhecimento (saber). Nela são consideradas as limitações e potencialidades dos sujeitos como um ser integral. Assim, carece uma articulação de outros saberes, como o "saber ser" (atitudes) ou mesmo "saber fazer" (habilidades). Dessa forma, Behar et al (2013, p.26) definiram que "[...] o indivíduo é competente quando é capaz de "saber", "saber fazer" e de "saber ser", que são associados aos elementos do CHA".

O CHA é a sigla utilizada para Conhecimento, Habilidade e Atitude. O Conhecimento está associado ao saber de um sujeito, pelo qual ele pode ser construído. Para Perrenoud (2013, p.1-2), conhecimentos "são representações da realidade, que construímos e armazenamos ao sabor de nossa experiência e de nossa formação". Já a Habilidade está relacionada ao "saber fazer”, ou seja, “[...] uma ação automatizada, um procedimento já construído, algo da ordem do operacional, não exigindo se deter em uma reflexão mais aprofundada" (BEHAR, et al, 2013, p.28). Este elemento esteve, por muitos anos, e até hoje, como sinônimo da palavra competência. No entanto, observa-se cada vez mais que a Habilidade faz parte e não pode ser considerada apenas como outra opção do uso do termo de competência.

A Atitude refere-se ao "saber ser", e, portanto, está relacionada com os valores e normas de cada sujeito (BEHAR et al, 2013; PERRENOUD, 2013). Ela é primordial na mobilização das competências, pois permite um engajamento, ou não, do sujeito para o enfrentamento de situações que possam surgir. "Para haver competência, é preciso uma atitude a favor das ações de resolução, enfrentamento, superação" (BEHAR et al, 2013, p.29).

Com a propagação e uso das tecnologias digitais (TD), algumas competências foram agregadas, sendo necessário considerar o uso de recursos e ferramentas aos saberes. Portanto, as competências digitais, ou como alguns autores chamam alfabetização ou letramento digital, começaram a ser discutidas nos anos 90 a partir da evolução das tecnologias (INSTEFJORD, MONTHE, 2017; SILVA, 2018). Glister, em 1997, foi um dos primeiros autores a trabalhar com o tema, definindo como "[...] a capacidade de entender e usar informações em vários formatos a partir de uma ampla gama de fontes quando é apresentada via computadores" (GLISTER, 1997, p.1). 
A competência digital pode ser definida como. "[...] a utilização segura, crítica e criativa das Tecnologias de Informação e Comunicação (TIC) para alcançar objetivos mais amplos relacionados com o emprego, a educação, o trabalho, o lazer, a inclusão e a participação na sociedade" (PATRICIO, OSÓRIO, 2017, p.3). Essa breve definição de competência digital revela que a mesma se relaciona com muitos aspectos da vida (trabalho, lazer, comunicação) e vai além do conhecimento e habilidades técnicas, pois se refere à confiança e a uma atitude crítica frente às tecnologias. Na competência digital podem ser apontadas algumas específicas que são primordiais. Vázquez-Cano e Sevillano (2015) apresentam cinco competências essenciais, que são: organizar, buscar, comunicar, produzir e publicar. Outros estudos já relacionam a CD com as de alfabetização, letramento e fluência digital (LINS, 2017; SILVA, 2018b). No ERE não há estudos sobre as competências digitais, sendo ainda um campo novo. Garcia (2020, p.10) aponta o que o professor deve considerar no aluno em ERE:

a) que conhecimentos ele domina: quanto ao conteúdo, à tecnologia, ao uso e à aplicação de ferramentas etc.;

b) qual o status de confiança, interesse e motivações pessoais;

c) quanto à aprendizagem, por que estuda, quais os hábitos de estudo, que métodos costuma utilizar?

d) quais as habilidades da aprendizagem são de mais uso e domínio: memorização, resolução de problemas, interpretação, aplicação?

e) quais estratégias de fixação da aprendizagem o estudante adota na rotina de estudos: cópia, resumo, sínteses, revisão, mapas conceituais ou mentais etc.

Assim, com base nos apontamentos de Garcia (2020), é possível perceber que indícios sobre os conhecimentos, habilidades e atitudes para o ensino remoto já existem, mas é necessário uma organização e apresentação sobre as CD. Portanto, é importante cada vez mais discutir e possibilitar ações para que os docentes possam construir estas competências com diferentes públicos, pois, como sinalizado pelo parlamento Europeu e o Conselho da União Europeia, a competência digital é uma entre as oito mais importantes, que deve ser incluída em programas de aprendizagem ao longo da vida (EUROPEAN COMMISSION, 2010; FERRARI, 2006). Desta forma, é possível perceber que a construção de competências digitais é necessária no ERE, o que pressupõe uma análise e discussão sobre a sua aplicação, conforme apresentado nas seções a seguir.

\section{Metodologia}

A presente pesquisa teve uma abordagem qualitativa do tipo interpretativa, de natureza aplicada, sendo exploratória quanto aos objetivos e como procedimento foi utilizado estudo de caso. O público-alvo foram professores que participaram de um curso, ofertado em julho de 2020, de extensão a distância em uma universidade pública de Santa Catarina. Esse teve por finalidade abordar o uso de metodologias para o ensino remoto, incluindo a discussão sobre as competências digitais. Para atender ao objetivo principal da pesquisa, que foi mapear as competências digitais para alunos no ensino remoto, a investigação teve quatro etapas.

Na primeira etapa, de coleta de dados, foi questionado, em um Ambiente Virtual de Aprendizagem (AVA), quais Conhecimentos, Habilidades e Atitudes eram necessários para os alunos utilizarem as tecnologias digitais no ERE. Assim, cada participante elencou os elementos do CHA, definindo o público e intercalando com saberes específicos das áreas que atuavam. Esses apontamentos foram apresentados de forma individual no AVA e descritos pelos pesquisadores para a análise geral das informações. Cabe salientar que anteriormente foi realizado, em um encontro síncrono, uma apresentação e discussão sobre o conceito de 
competências digitais e de seus elementos: Conhecimentos, Habilidades, Atitudes. Essa base viabilizou aos participantes um entendimento maior para responder no AVA.

A segunda etapa consistiu em classificar os conhecimentos, habilidades e atitudes em dois grupos: digitais ou não digitais (específicos às áreas de atuação dos participantes). Também foi realizada uma separação por público-alvo destinado ao ERE. Nessa fase foram utilizados os passos de Bardin (2010), que aponta a necessidade de uma leitura e análise geral para, em seguida, categorizar as informações. Assim, para uma análise detalhada, foi identificado: os CHA repetidos (citados mais de uma vez pelos participantes), que foram retirados, além da necessidade de correção ortográfica ou gramatical dos apontamentos.

$\mathrm{Na}$ terceira etapa, foi realizada a categorização do CHA em competências digitais, sendo possível nomeá-las de acordo com os saberes (saber, saber fazer, saber ser) indicados pelos participantes. Também nessa etapa foi necessário conceituar cada competência de acordo com a categorização concretizada do CHA. Por fim, na etapa quatro da pesquisa, foi realizada uma leitura crítica das informações para padronizar os verbos utilizados, assim como ajustar cada elemento da competência.

\section{Resultados e Discussão}

A presente pesquisa teve como objetivo mapear as competências digitais para alunos no ensino remoto. Assim, os sujeitos da pesquisa foram professores de diferentes áreas que participaram de um curso de extensão em uma universidade no Brasil. Esse curso teve por finalidade identificar, a partir das experiências dos docentes, os conhecimentos, habilidades e atitudes necessárias aos alunos de diferentes formações para atuarem no ERE. Assim, para um melhor entendimento sobre a pesquisa, os dados foram separados em: Perfil dos participantes, Conhecimentos, Habilidades e Atitudes, Competências Digitais para ERE.

\subsection{Perfil dos participantes}

Os participantes da pesquisa, que totalizaram 29, apontaram o CHA necessário para os alunos atuarem no ERE. Assim, desde total de sujeitos, 4 eram do sexo masculino e 25 do feminino. Já a idade variou entre 20-50 anos. Os sujeitos eram oriundos de áreas do conhecimento e atuação distintos: Ensino Fundamental II (n=3), Ensino Médio (n=5), Ensino Técnico $(n=3)$, Ensino Superior $(n=18)$. No Ensino Superior, as disciplinas abrangidas foram desde as áreas da saúde, como enfermagem, fisioterapia, licenciatura em Pedagogia, Educação Física, Engenharias, entre outras. Esses dados apontam que o público investigado possui uma formação no Ensino Superior, com experiência e oriundo de diferentes áreas do conhecimento, o que permitiu um enriquecimento nos dados coletados.

\subsection{Conhecimentos, Habilidades e Atitudes}

No intuito de identificar as CD para o ERE, os participantes foram indagados sobre os conhecimentos, habilidades e atitudes (CHA) necessários para os alunos participarem dessa modalidade de ensino. Assim, ao todo foram mapeados 51 elementos do CHA para o Ensino Fundamental II e Médio, 12 para o Ensino Técnico e 172 para o Ensino Superior, conforme apresentado na Figura 1. 
Figura 1 - Gráfico dos Conhecimentos, Habilidades e Atitudes digitais dos alunos do ER.

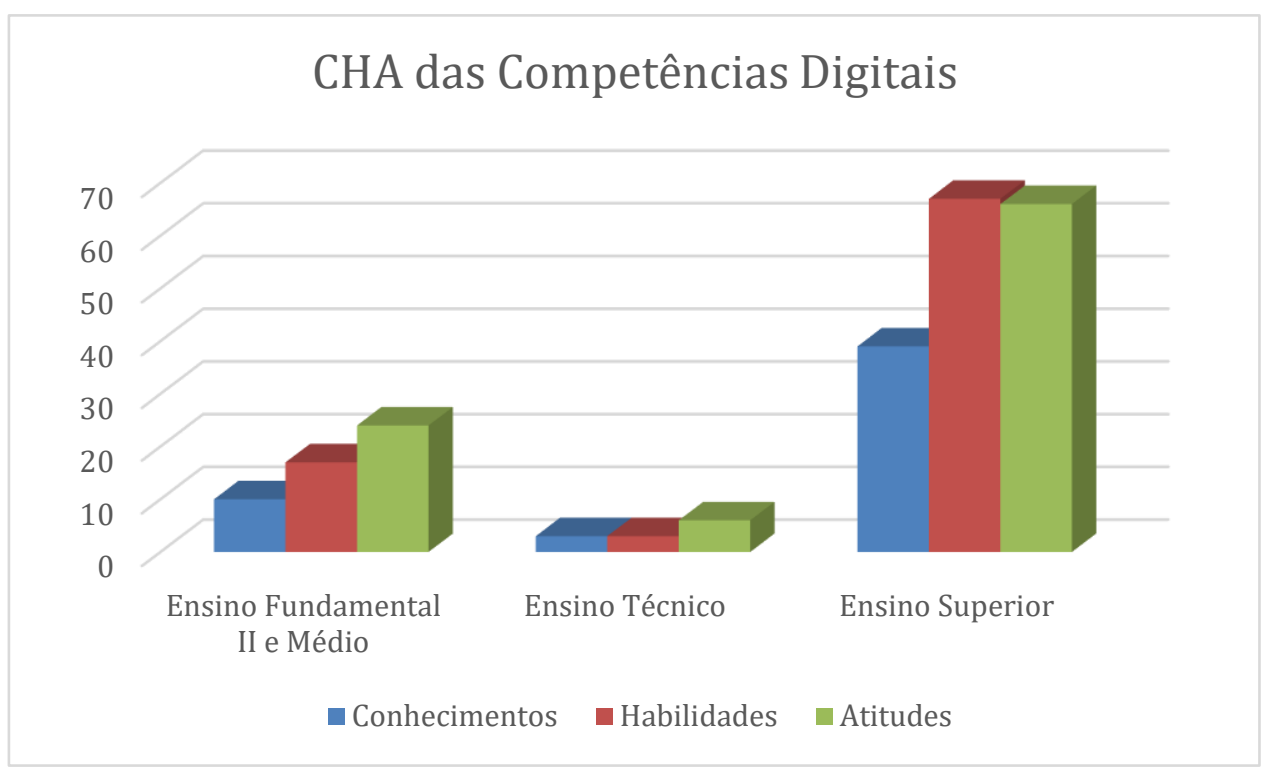

Fonte: Os autores (2021).

Em relação aos CHA específicos, ou seja, os relacionados com cada área do conhecimento do professor participante e não vinculada às digitais, foram identificadas 10 para o Ensino Fundamental II e Médio, 6 para o Ensino Técnico e 54 para o Ensino Superior, conforme a Figura 2 apresenta.

Figura 2 - Gráfico dos Conhecimentos, Habilidades e Atitudes específicos dos alunos do ER.

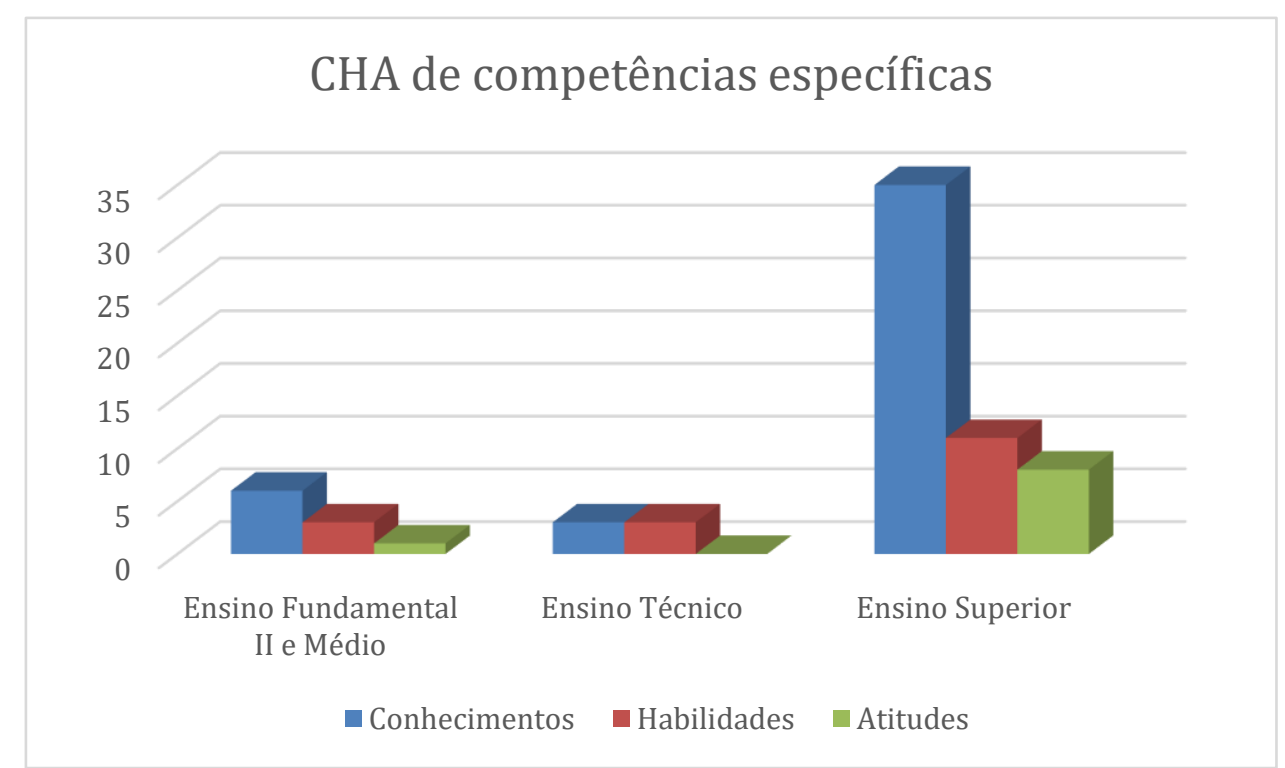

Fonte: Os autores (2021).

No entanto, considerando que o foco deste trabalho está relacionado com as competências digitais, o CHA das áreas específicas não serão contempladas nesse estudo, sendo 
analisadas apenas as vinculadas ao uso de recursos tecnológicos. Assim, ao analisar o CHA citado pelos professores participantes, pode-se perceber que muitos possuíam compreensão de como identificá-las, assim como a necessidade de iniciar a escrita com um verbo no infinitivo, sendo que poucos $(n=4)$ foram os participantes que trocaram as atitudes pelas habilidades ou vice-versa.

Para iniciar a análise dos dados, foi realizada uma leitura geral dos conhecimentos, habilidades e atitudes apontados pelos participantes. Em seguida, os mesmos foram categorizados em competências digitais específicas, de acordo com as características dos conhecimentos, habilidades e atitudes apresentados. Os CHA do Ensino Fundamental II e Médio apresentaram mais elementos voltados para o uso básico das tecnologias, focando, principalmente, na utilização de ferramentas de comunicação como WhatsApp. Isso refletem as práticas pedagógicas relatadas por professores da Educação Básica que estão aplicando o Ensino Remoto e estão com dificuldades básicas no uso das TD, assim como a necessidade, em alguns casos, do auxílio de pais ou responsáveis para que os alunos possam acessar os materiais e recursos disponibilizados (SARAIVA et al, 2020).

Os CHA do Ensino Superior, assim como Ensino Técnico, foram apresentados com foco nos recursos vinculados ao uso de um Ambiente Virtual de Aprendizagem (AVA) e videoconferência. Os conhecimentos foram mais concentrados nos conteúdos disciplinares. Moreira, Henriques e Barros (2020, p.354) citam que

\footnotetext{
É recomendável que no ambiente virtual exista pelo menos um espaço de comunicação para as notícias e avisos; um espaço para as dúvidas que os estudantes possuam; um espaço informal onde os estudantes possam interagir de forma mais descontraída; e diferentes espaços criados em cada tópico para as atividades que se possam desenvolver em cada tema.
}

Os indicativos da necessidade no uso de um AVA refletem uma realidade que abrange quase todas as instituições do Ensino Técnico, assim como Superior, já que é comum, muitas vezes, mesclar práticas híbridas e da modalidade EaD. Portanto, considerando todos o CHA apresentados, pode-se observar que os professores participantes possuem uma clareza sobre as necessidades dos seus alunos, assim como suas limitações no que diz respeito às habilidades no uso das TD, bem como a importância de atitudes proativas para o ERE. Assim, para uma melhor compreensão, as competências foram divididas em: Ensino Fundamental II e Médio, Ensino Técnico e Ensino Superior.

\subsection{Competências Digitais para ERE}

O mapeamento do CHA apontado pelos participantes propiciou que fosse possível identificar as competências digitais por modalidade. No Ensino Fundamental II e Médio, o CHA foi classificado em 3 competências digitais. Algumas habilidades e atitudes foram citadas mais de uma vez pelos participantes, como é o caso da proatividade que apareceu 4 vezes, atitude de "disciplina" apontada 2 vezes, resiliência apresentada 2 vezes. No entanto, outros elementos apareceram com uma escrita diferente, mas com a mesma ideia principal vinculada. Nesses casos, os elementos foram suprimidos ou retirados para não haver confusão nas CD. Assim, para o Ensino Fundamental II e Médio foram identificadas 3 competências digitais para o ERE: 
a) Utilização básica do computador (desktop) e/ou dispositivo móvel: essa está relacionada com o uso básico do computador e dispositivo móvel, como smartphone, para o acesso e participação das aulas remotas.

b) Letramento Digital: está relacionada à leitura e à escrita crítica através de uma tecnologia digital.

c) Comunicação através de videoconferência: essa está relacionada ao uso seguro de ferramentas de comunicação, por vídeo e voz, para a participação de aulas remotas.

Portanto, a seguir são apresentados os conhecimentos, habilidades e atitudes de cada uma dessas competências para o Ensino Fundamental II e Médio, conforme consta no Quadro 1 .

Quadro 1 - Competências Digitais do Ensino Fundamental II e Médio.

COMPETÊNCIAS DIGITAIS PARA AULA REMOTA - ENSINO FUNDAMENTAL II E MÉDIO

\begin{tabular}{|c|c|c|c|}
\hline $\begin{array}{c}\text { Competência } \\
\text { Digital }\end{array}$ & Conhecimentos & Habilidades & Atitudes \\
\hline $\begin{array}{l}\text { Utilização } \\
\text { básica do } \\
\text { computador } \\
\text { (desktop) } \\
\text { e/ou } \\
\text { dispositivo } \\
\text { móvel }\end{array}$ & $\begin{array}{l}\text {-Compreender } \\
\text { sobre as } \\
\text { funcionalidades } \\
\text { básicas de um } \\
\text { computador } \\
\text { ou smartphone. } \\
\text {-Conhecer os } \\
\text { aplicativos } \\
\text { móveis } \\
\text { Noções sobre } \\
\text { Internet. }\end{array}$ & $\begin{array}{l}\text {-Manusear de maneira adequada um } \\
\text { dispositivo móvel e ou um computador } \\
\text { pessoal. } \\
\text {-Navegar na internet, nos diferentes sítios } \\
\text { apresentados. } \\
\text {-Busca na internet. } \\
\text {-Selecionar ferramentas digitais que } \\
\text { possam auxiliar. } \\
\text {-Convívio digital (redes sociais como } \\
\text { ferramenta de troca de informações e } \\
\text { arquivos). } \\
\text {-Ter conhecimento sobre como mexer na } \\
\text { internet (realizar pesquisas, } \\
\text { principalmente). } \\
\text {-Instalação do aplicativo. } \\
\text {-Assistir vídeos. } \\
\text {-Verificar problemas com a conexão. }\end{array}$ & $\begin{array}{l}\text {-Resiliência digital. } \\
\text {-Curadoria de conteúdos } \\
\text { na internet. } \\
\text {-Ser um sujeito tolerante à } \\
\text { opinião de outros. } \\
\text {-Saber organizar-se. } \\
\text {-Proatividade. } \\
\text {-Comprometimento. } \\
\text {-Disciplina. }\end{array}$ \\
\hline $\begin{array}{l}\text { Letramento } \\
\text { digital }\end{array}$ & $\begin{array}{l}\text {-Conhecer os } \\
\text { recursos digitais e } \\
\text { suas } \\
\text { possibilidades. } \\
\text {-Leitura e escrita. }\end{array}$ & $\begin{array}{l}\text {-Busca na internet. } \\
\text {-Selecionar ferramentas digitais que } \\
\text { possam auxiliar. } \\
\text {-Manusear de maneira adequada um } \\
\text { dispositivo móvel e ou um computador } \\
\text { pessoal. } \\
\text {-Navegar na internet, nos diferentes sítios } \\
\text { apresentados. } \\
\text {-Interpretar os diferentes tipos de textos, } \\
\text { sejam eles escritos ou não } \\
\text { escrita de texto. } \\
\text {-Utilização de plataforma de edição de } \\
\text { texto compartilhada. } \\
\text {-Organizar e planejar a escrita. } \\
\text {-Fazer a leitura dos conteúdos } \\
\text { disponibilizados. } \\
\text {-Utilizar estratégias de estudo. }\end{array}$ & $\begin{array}{l}\text {-Resiliência digital. } \\
\text {-Fazer com dedicação as } \\
\text { atividades propostas pelo } \\
\text { professor. } \\
\text {-Refletir sobre os } \\
\text { conteúdos postados. } \\
\text {-Desenvolvimento do } \\
\text { senso crítico. } \\
\text {-Curadoria de conteúdos } \\
\text { na internet. } \\
\text {-Ser um sujeito tolerante à } \\
\text { opinião de outros. } \\
\text {-Saber organizar-se. } \\
\text {-Proatividade. } \\
\text {-Comprometimento. } \\
\text {-Disciplina. } \\
\text {-Ser dedicado(a). }\end{array}$ \\
\hline $\begin{array}{l}\text { Comunicação } \\
\text { através de }\end{array}$ & $\begin{array}{l}\text {-Conhecer suas } \\
\text { dificuldades. }\end{array}$ & -Instalação do aplicativo. & -Resiliência digital. \\
\hline
\end{tabular}




\begin{tabular}{|c|c|c|c|}
\hline $\begin{array}{l}\text { videoconferên } \\
\text { cia }\end{array}$ & $\begin{array}{l}\text {-Domínio básico } \\
\text { da utilização do } \\
\text { desktop e/ou } \\
\text { dispositivos } \\
\text { móveis. } \\
\text {-Conhecimentos } \\
\text { básicos do } \\
\text { aplicativo Google } \\
\text { Hangouts. } \\
\text {-Compreender } \\
\text { sobre as } \\
\text { funcionalidades } \\
\text { da } \\
\text { plataforma Teams }\end{array}$ & $\begin{array}{l}\text {-Manusear de maneira adequada um } \\
\text { dispositivo móvel e ou um computador } \\
\text { pessoal. } \\
\text {-Utilizar os recursos digitais } \\
\text { disponibilizados. } \\
\text {-Saber realizar e atender videochamadas } \\
\text { em grupo. } \\
\text {-Trabalho em equipe. } \\
\text {-Acesso online a plataforma. } \\
\text {-Acompanhar as explicações remotamente } \\
\text { e exercitar o conteúdo aprendido com } \\
\text { atividades. } \\
\text {-Verificar problemas com a conexão. }\end{array}$ & $\begin{array}{l}\text {-Fazer com dedicação as } \\
\text { atividades propostas pelo } \\
\text { professor. } \\
\text {-Refletir sobre os } \\
\text { conteúdos postados. } \\
\text {-Ser um sujeito tolerante à } \\
\text { opinião de outros. } \\
\text {-Ter disciplina para manter } \\
\text { uma rotina. } \\
\text {-Proatividade. } \\
\text {-Comprometimento. } \\
\text {-Disciplina. } \\
\text {-Ser dedicado(a). }\end{array}$ \\
\hline
\end{tabular}

Fonte: Os autores (2021).

No Ensino Técnico os conhecimentos, habilidades e atitudes foram divididos em duas competências digitais:

a) Utilização de Ambiente Virtual de Aprendizagem (AVA): está relacionado ao uso crítico de um AVA pelos alunos para a participação das aulas remotas.

b) Comunicação através de videoconferência: essa está relacionada ao uso seguro de ferramentas de comunicação por vídeo e voz para a participação de aulas remotas.

Portanto, a seguir, no Quadro 2, é apresentado os conhecimentos, habilidades e atitudes de cada uma dessas competências para o Ensino Técnico.

Quadro 2 - Competências Digitais do Ensino Técnico.

\section{COMPETÊNCIAS DIGITAIS PARA AULA REMOTA - ENSINO TÉCNICO}

\begin{tabular}{|c|c|c|c|}
\hline $\begin{array}{l}\text { Competência } \\
\text { Digital }\end{array}$ & Conhecimentos & Habilidades & Atitudes \\
\hline $\begin{array}{l}\text { Utilização de } \\
\text { Ambiente } \\
\text { Virtual de } \\
\text { Aprendizage } \\
\text { m (AVA) }\end{array}$ & $\begin{array}{l}\text {-Conhecer o } \\
\text { Ambiente Virtual } \\
\text { de Aprendizagem } \\
\text { (AVA) Moodle } \\
\text {-Conhecer a } \\
\text { plataforma Google } \\
\text { Classroom. }\end{array}$ & $\begin{array}{l}\text {-Saber navegar e } \\
\text { usar as } \\
\text { funcionalidades } \\
\text { do AVA Moodle. } \\
\text {-Saber navegar e } \\
\text { usar a plataforma } \\
\text { Google } \\
\text { Classroom. }\end{array}$ & $\begin{array}{l}\text {-Proatividade. } \\
\text {-Comprometimento. } \\
\text {-Respeito. } \\
\text {-Saber trabalhar em equipe para produzir } \\
\text { conhecimentos de forma colaborativa. } \\
\text {-Ter curiosidade para aprender sobre as novas } \\
\text { Tecnologias de Informação e Comunicação. } \\
\text {-Ter disciplina, organização e responsabilidade } \\
\text { para realizar as atividades programadas nas aulas } \\
\text { remotas. }\end{array}$ \\
\hline $\begin{array}{l}\text { Comunicação } \\
\text { através de } \\
\text { videoconferên } \\
\text { cia }\end{array}$ & $\begin{array}{l}\text {-Conhecer a } \\
\text { ferramenta de } \\
\text { videoconferência } \\
\text { Webex. }\end{array}$ & $\begin{array}{l}\text {-Saber navegar e } \\
\text { usar as } \\
\text { funcionalidades } \\
\text { da plataforma } \\
\text { Webex. }\end{array}$ & $\begin{array}{l}\text {-Proatividade. } \\
\text {-Comprometimento. } \\
\text {-Respeito. } \\
\text {-Ter curiosidade para aprender sobre as novas } \\
\text { Tecnologias de Informação e Comunicação. } \\
\text {-Ter disciplina, organização e responsabilidade } \\
\text { para realizar as atividades programadas nas aulas } \\
\text { remotas. }\end{array}$ \\
\hline
\end{tabular}

Fonte: Os autores (2021)

No Ensino Superior, houve mais participantes e, portanto, mais CHA foram apresentados. Assim, foram mapeadas 5 competências digitais: 
a) Utilização básica do computador (desktop) e/ou dispositivo móvel: está relacionada com o uso básico do computador e dispositivo móvel, como smartphone, para o acesso e participação das aulas remotas.

b) Utilização de Ambiente Virtual de Aprendizagem: está relacionada ao uso crítico de AVA pelos alunos para a participação das aulas remotas.

c) Comunicação através de videoconferência: está relacionada ao uso seguro de ferramentas de comunicação por vídeo e voz para a participação de aulas remotas.

d) Cooperação: está relacionada ao trabalho em equipe, no qual cada estudante tem um objetivo em comum e utilizam as TD para interagir e se comunicar.

e) Produção de material digital: está relacionada ao planejamento e produção de materiais digitais no intuito de compartilhar em um AVA ou responder em redes sociais e outras ferramentas.

No Quadro 3, são apresentados os conhecimentos, habilidades e atitudes de cada competência digital para o ERE do Ensino Superior.

Quadro 3 - Competências Digitais do Ensino Superior.

\section{COMPETENNCIAS DIGITAIS PARA AULA REMOTA - ENSINO SUPERIOR}

\begin{tabular}{|c|c|c|c|}
\hline $\begin{array}{c}\text { Competência } \\
\text { Digital }\end{array}$ & Conhecimentos & Habilidades & Atitudes \\
\hline $\begin{array}{l}\text { Utilização básica } \\
\text { do computador } \\
\text { (desktop) e/ou } \\
\text { dispositivo móvel }\end{array}$ & $\begin{array}{l}\text {-Conhecer as } \\
\text { funcionalidades } \\
\text { básicas dos } \\
\text { aparelhos a } \\
\text { serem utilizados } \\
\text { (computador/dis } \\
\text { positivos } \\
\text { móveis). } \\
\text {-Conhecimento } \\
\text { sobre e-mail. } \\
\text {-Ferramentas de } \\
\text { interação. } \\
\text {-Noçóes básicas } \\
\text { de informática. } \\
\text {-Proteção de } \\
\text { dados pessoais. } \\
\text {-Conhecimento } \\
\text { sobre como } \\
\text { entrar em } \\
\text { plataformas. } \\
\text {-Saber usar } \\
\text { computador, } \\
\text { acessar internet } \\
\text { e ter domínio } \\
\text { como usuário de } \\
\text { plataformas de } \\
\text { web } \\
\text { conferência. } \\
\text {-Saber usar } \\
\text { diferentes } \\
\text { mídias digitais } \\
\text { para consulta e }\end{array}$ & $\begin{array}{l}\text {-Saber utilizar o computador de mesa } \\
\text { (desktop) ou dispositivos móveis. } \\
\text {-Domínio básico de ferramentas de } \\
\text { busca. } \\
\text {-Saber utilizar ferramentas e filtros de } \\
\text { busca. } \\
\text {-Saber filtrar o fluxo de informação } \\
\text { além da capacidade de construir } \\
\text { conhecimento a partir de } \\
\text { informações. } \\
\text {-Saber utilizar e-mail para enviar } \\
\text { perguntas aos professores se } \\
\text { necessário. } \\
\text {-Gerenciamento da informação. } \\
\text {-Comunicação. } \\
\text {-Domínio básico de informática. } \\
\text {-Saber utilizar as tecnologias digitais } \\
\text { para interagir com os colegas. } \\
\text {-Buscar conhecimento em bases de } \\
\text { dados. } \\
\text {-Saber mexer em diferentes } \\
\text { tecnologias. } \\
\text {-Capacidade de procurar ajudas e } \\
\text { orientações nos momentos de } \\
\text { dificuldade. } \\
\text {-Buscar aplicativos e sites que } \\
\text { mostrem os mesmos aspectos } \\
\text { científicos identificados. }\end{array}$ & $\begin{array}{l}\text {-Curiosidade. } \\
\text {-Criatividade. } \\
\text {-Interesse. } \\
\text {-Dedicação. } \\
\text {-Perseverança. } \\
\text {-Autonomia. } \\
\text {-Pró-atividade para realizar } \\
\text { atividades remotas. } \\
\text {-Foco. } \\
\text {-Responsabilidade ética. } \\
\text {-Participação significativa. } \\
\text {-Paciência. } \\
\text {-Automotivação. } \\
\text {-Ter motivação e vontade } \\
\text { de participar de forma } \\
\text { ativa, aberto e engajado em } \\
\text { diferentes atividades } \\
\text { propostas. } \\
\text {-Estar aberto para estudar e } \\
\text { aprender nessa nova } \\
\text { modalidade de ensino. }\end{array}$ \\
\hline
\end{tabular}




\begin{tabular}{|c|c|c|c|}
\hline & $\begin{array}{l}\text { busca de } \\
\text { informações. } \\
\text {-Saber lidar com } \\
\text { problemas nesse } \\
\text { momento } \\
\text { anormal da } \\
\text { pandemia, tanto } \\
\text { a nível pessoal } \\
\text { como coletivo. }\end{array}$ & & \\
\hline $\begin{array}{l}\text { Utilização de } \\
\text { Ambiente } \\
\text { Virtual de } \\
\text { Aprendizagem } \\
\text { (AVA) }\end{array}$ & $\begin{array}{l}\text {-Conhecer o } \\
\text { espaço do } \\
\text { ambiente virtual } \\
\text { de } \\
\text { aprendizagem } \\
\text { (Moodle). } \\
\text {-Conhecer os } \\
\text { recursos básicos } \\
\text { do ambiente } \\
\text { virtual para } \\
\text { produção de } \\
\text { conteúdo e } \\
\text { compartilhamen } \\
\text { to de } \\
\text { informações. } \\
\text {-Saber } \\
\text { diferenciar } \\
\text { acesso síncrono } \\
\text { e assíncrono, ou } \\
\text { seja, como as } \\
\text { aulas serão } \\
\text { transmitidas. } \\
\text {-Busca de } \\
\text { informação. } \\
\text {-Proteção de } \\
\text { dados pessoais. } \\
\text {-Compreender } \\
\text { as } \\
\text { especificidades } \\
\text { do ensino } \\
\text { remoto. } \\
\text {-Conhecer as } \\
\text { suas } \\
\text { necessidades de } \\
\text { aprendizagem, } \\
\text { seu processo de } \\
\text { aprendizagem e } \\
\text { o sistema de } \\
\text { avaliação no } \\
\text { período de } \\
\text { pandemia. } \\
\text {-Saber lidar com } \\
\text { problemas nesse } \\
\text { momento } \\
\text { anormal da } \\
\text { pandemia, tanto } \\
\text { a nível pessoal } \\
\text { como coletivo. }\end{array}$ & $\begin{array}{l}\text {-Saber utilizar as ferramentas básicas } \\
\text { do ambiente virtual de aprendizagem } \\
\text { (Moodle). } \\
\text {-Habilidade de organizar o conteúdo } \\
\text { da aula. } \\
\text {-Habilidade de eleger os pontos } \\
\text { principais do conteúdo. } \\
\text {-Utilizar o Moodle para encontrar } \\
\text { materiais utilizados na aula. } \\
\text {-Postar em fóruns e realizar provas e } \\
\text { atividades avaliativas. } \\
\text {-Gerenciamento da informação. } \\
\text {-Comunicação. } \\
\text {-Colaboração. } \\
\text {-Acesso e manuseio da plataforma } \\
\text { Moodle conhecendo as principais } \\
\text { ferramentas a serem utilizadas como: } \\
\text { tarefas, fórum de dúvidas, fórum de } \\
\text { discussão e chat. } \\
\text {-Manter-se organizados na situação } \\
\text { de ensino remoto. } \\
\text {-Buscar conhecimento em bases de } \\
\text { dados. } \\
\text {-Habilidades para dialogar ou } \\
\text { comunicar as suas principais } \\
\text { demandas e tarefas. } \\
\text {-Habilidades de colaborar e trabalhar } \\
\text { em grupo com colegas. } \\
\text {-Capacidade de interpretar } \\
\text { informações. } \\
\text {-Capacidade de escrever e falar de } \\
\text { forma clara, coerente e resumida. } \\
\text {-Habilidade de participar em várias } \\
\text { atividades de forma individual ou } \\
\text { coletiva. } \\
\text {-Habilidades de realizar tarefas, } \\
\text { usando diferentes ferramentas e } \\
\text { meios digitais disponíveis. } \\
\text {-Capacidade de estudar de forma } \\
\text { independente. } \\
\text {-Habilidades de usar o tempo de } \\
\text { forma eficiente para executar várias } \\
\text { tarefas dentro do prazo pré- } \\
\text { estabelecido. } \\
\text {-Capacidade de analisar o seu } \\
\text { interesse de aprendizagem, traçar } \\
\text { planos para implementação do seu } \\
\text { sistema, tendo em conta a sua } \\
\text { realidade. }\end{array}$ & $\begin{array}{l}\text {-Curiosidade. } \\
\text {-Criatividade. } \\
\text {-Interesse. } \\
\text {-Dedicação. } \\
\text {-Perseverança. } \\
\text {-Autonomia. } \\
\text {-Proatividade. } \\
\text {-Foco. } \\
\text {-Ter uma atitude proativa } \\
\text { em relação a busca de } \\
\text { soluçoses para problemas } \\
\text { que possam surgir no } \\
\text { contato inicial com a } \\
\text { plataforma (Moodle). } \\
\text {-Ter uma atitude de } \\
\text { cooperação no ambiente } \\
\text { virtual de aprendizagem. } \\
\text {-Ter uma atitude de } \\
\text { resiliência virtual e de } \\
\text { convivência em rede. } \\
\text {-Pontualidade. } \\
\text {-Assiduidade. } \\
\text {-Curiosidade para explorar } \\
\text { materiais extras } \\
\text { disponíveis no Moodle. } \\
\text {-Ética para somente } \\
\text { utilizar do seu próprio } \\
\text { conhecimento e esforço ao } \\
\text { realizar provas e ao } \\
\text { escrever trabalhos } \\
\text { acadêmicos. } \\
\text {-Participação significativa. } \\
\text {-Paciência. } \\
\text {-Automotivação. } \\
\text {-Ser dedicado e } \\
\text { comprometido com o } \\
\text { processo de aprendizagem. } \\
\text {-Ter atitude e vontade de } \\
\text { colocar as suas ideias de } \\
\text { forma construtiva, } \\
\text { articulado e cauteloso. } \\
\text {-Ter preocupação em } \\
\text { alcançar os objetivos } \\
\text { individuais e coletivos, de } \\
\text { forma flexível e aberta as } \\
\text { sugestões e críticas } \\
\text { construtivas. } \\
\text {-Estar disposto a participar } \\
\text { efetivamente nas }\end{array}$ \\
\hline
\end{tabular}




\begin{tabular}{|c|c|c|c|}
\hline & & $\begin{array}{l}\text {-Capacidade de procurar ajudas e } \\
\text { orientações nos momentos de } \\
\text { dificuldade. } \\
\text {-Postar dúvidas e utilizar ativamente } \\
\text { o fórum de discussões. } \\
\text {-Interagir durante as aulas remotas e } \\
\text { postar as atividades no prazo } \\
\text { estipulado. } \\
\text {-Participar da aula usando chats e } \\
\text { questionando o professor. } \\
\text {-Buscar conhecimento sobre as } \\
\text { tecnologias existentes. } \\
\text {-Buscar mais conhecimento sobre o } \\
\text { tema ministrado. }\end{array}$ & $\begin{array}{l}\text { atividades síncronas e } \\
\text { assíncronas. } \\
\text {-Percepção de produzir ou } \\
\text { realizar o seu trabalho de } \\
\text { forma independente, sem } \\
\text { aproveitamento indevido } \\
\text { dos trabalhos de outros. } \\
\text {-Ter interesse e } \\
\text { perseverança de consultar } \\
\text { e buscar informações } \\
\text { complementares } \\
\text { necessárias para o } \\
\text { aprendizado e/ou } \\
\text { realização de atividades. } \\
\text {-Ter iniciativa de contatar } \\
\text { o professor quando } \\
\text { necessário para maiores } \\
\text { esclarecimentos. } \\
\text {-Interesse na resolução de } \\
\text { exercícios. } \\
\text {-Preocupação de consultar } \\
\text { normas técnicas e sites } \\
\text { recomendados nas aulas. } \\
\text {-Estar aberto para estudar e } \\
\text { aprender nessa nova } \\
\text { modalidade de ensino. }\end{array}$ \\
\hline $\begin{array}{l}\text { Comunicação } \\
\text { através de } \\
\text { videoconferência }\end{array}$ & $\begin{array}{l}\text {-Conhecimento } \\
\text { sobre } \\
\text { plataformas } \\
\text { digitais como o } \\
\text { Zoom. } \\
\text {-Conhecimento } \\
\text { de etiqueta para } \\
\text { aulas virtuais } \\
\text { (uso da câmera, } \\
\text { microfone, } \\
\text { barulho de } \\
\text { fundo). } \\
\text {-Conhecimento } \\
\text { sobre breakout } \\
\text { rooms do Zoom } \\
\text { e sobre } \\
\text { compartilhamen } \\
\text { to de arquivos. } \\
\text {-Proteção de } \\
\text { dados pessoais. } \\
\text {-Conhecer sobre } \\
\text { Plataformas de } \\
\text { videoconferênci } \\
\text { a (por exemplo } \\
\text { webconf). } \\
\text {-Compreender } \\
\text { as } \\
\text { especificidades } \\
\text { do ensino } \\
\text { remoto. } \\
\text {-Ter noção da } \\
\text { organização do } \\
\text { tempo e do }\end{array}$ & $\begin{array}{l}\text {-Saber anexar/enviar arquivos e } \\
\text { participar de webconferências como } \\
\text { ouvinte e como participante ativo } \\
\text { (habilitar câmera, áudio, participar de } \\
\text { chats). } \\
\text {-Utilizar links para se conectar à } \\
\text { plataforma Zoom. } \\
\text {-Iniciar e manter conversação e } \\
\text { discussão em breakout rooms. } \\
\text {-Saber compartilhar arquivos ao } \\
\text { participar de breakout rooms. } \\
\text {-Comunicação. } \\
\text {-Colaboração. } \\
\text {-Acesso e manuseio da plataforma } \\
\text { webconf para assistir às aulas } \\
\text { síncronas. } \\
\text {-Manter-se organizados na situação } \\
\text { de ensino remoto. } \\
\text {-Saber usar a plataforma de } \\
\text { videoconferência (postar do chat, } \\
\text { habilitar/desabilitar vídeo/áudio, } \\
\text { compartilhamento de tela). } \\
\text {-Capacidade de interpretar } \\
\text { informações. } \\
\text {-Capacidade de escrever e falar de } \\
\text { forma clara, coerente e resumida. } \\
\text {-Capacidade de procurar ajudas e } \\
\text { orientações nos momentos de } \\
\text { dificuldade. }\end{array}$ & $\begin{array}{l}\text {-Curiosidade. } \\
\text {-Criatividade. } \\
\text {-Interesse. } \\
\text {-Dedicação. } \\
\text {-Perseverança. } \\
\text {-Autonomia. } \\
\text {-Pró-atividade para realizar } \\
\text { atividades remotas. } \\
\text {-Foco. } \\
\text {-Ter uma atitude de } \\
\text { resiliência virtual e de } \\
\text { convivência em rede. } \\
\text {-Pontualidade. } \\
\text {-Assiduidade. } \\
\text {-Paciência. } \\
\text {-Automotivação. } \\
\text {-Estar aberto para estudar e } \\
\text { aprender nessa nova } \\
\text { modalidade de ensino. }\end{array}$ \\
\hline
\end{tabular}




\begin{tabular}{|c|c|c|c|}
\hline & $\begin{array}{l}\text { autoconhecimen } \\
\text { to. } \\
\text {-Compreender } \\
\text { formas de } \\
\text { comunicação e } \\
\text { de } \\
\text { comportamento } \\
\text { em aulas e } \\
\text { atividades } \\
\text { síncronas. } \\
\text {-Saber lidar com } \\
\text { problemas nesse } \\
\text { momento } \\
\text { anormal da } \\
\text { pandemia, tanto } \\
\text { a nível pessoal } \\
\text { como coletivo. }\end{array}$ & & \\
\hline Cooperação & $\begin{array}{l}\text {-Leitura } \\
\text {-Discussão em } \\
\text { grupo. } \\
\text {-Ferramentas de } \\
\text { interação. } \\
\text {-Conhecer } \\
\text { tecnologias } \\
\text { digitais que } \\
\text { propiciem o } \\
\text { desenvolviment } \\
\text { o do trabalho } \\
\text { virtual em } \\
\text { grupo. } \\
\text {-Ter noção da } \\
\text { organização do } \\
\text { tempo e do } \\
\text { autoconhecimen } \\
\text { to. } \\
\text {-Conhecer bem } \\
\text { os membros da } \\
\text { equipe do } \\
\text { trabalho de } \\
\text { grupo. } \\
\text {-Saber lidar com } \\
\text { problemas nesse } \\
\text { momento } \\
\text { anormal da } \\
\text { pandemia, tanto } \\
\text { a nível pessoal } \\
\text { como coletivo. }\end{array}$ & $\begin{array}{l}\text {-Domínio básico de ferramentas de } \\
\text { busca. } \\
\text {-Saber utilizar ferramentas e filtros de } \\
\text { busca. } \\
\text {-Saber filtrar o fluxo de informação } \\
\text { além da capacidade de construir } \\
\text { conhecimento a partir de } \\
\text { informações. } \\
\text {-Habilidade de eleger os pontos } \\
\text { principais do conteúdo. } \\
\text {-Trabalhar em equipe. } \\
\text {-Concentração. } \\
\text {-Gerenciamento da informação. } \\
\text {-Comunicação. } \\
\text {-Colaboração. } \\
\text {-Manter-se organizados na situação } \\
\text { de ensino remoto. } \\
\text {-Saber engajar-se com os outros } \\
\text { alunos, monitores ou professores } \\
\text { (trabalho em equipe). } \\
\text {-Buscar conhecimento em bases de } \\
\text { dados. } \\
\text {-Habilidades para dialogar ou } \\
\text { comunicar as suas principais } \\
\text { demandas e tarefas. } \\
\text {-Habilidades de colaborar e trabalhar } \\
\text { em grupo com colegas. } \\
\text {-Capacidade de interpretar } \\
\text { informações. } \\
\text {-Capacidade de escrever e falar de } \\
\text { forma clara, coerente e resumida. } \\
\text {-Habilidade de lidar com grande } \\
\text { volume de informações em curto } \\
\text { espaço de tempo. } \\
\text {-Habilidades de usar o tempo de } \\
\text { forma eficiente para executar várias } \\
\text { tarefas dentro do prazo pré- } \\
\text { estabelecido. } \\
\text {-Capacidade de procurar ajudas e } \\
\text { orientações nos momentos de } \\
\text { dificuldade. }\end{array}$ & $\begin{array}{l}\text {-Curiosidade. } \\
\text {-Criatividade. } \\
\text {-Interesse. } \\
\text {-Dedicação. } \\
\text {-Perseverança. } \\
\text {-Autonomia. } \\
\text {-Pró-atividade para realizar } \\
\text { atividades remotas. } \\
\text {-Foco. } \\
\text {-Ter uma atitude de } \\
\text { resiliência virtual e de } \\
\text { convivência em rede. } \\
\text {-Abertura para resolução } \\
\text { de problemas. } \\
\text {-Vontade de compartilhar e } \\
\text { trocar ideias, informações, } \\
\text { dúvidas. } \\
\text {-Pontualidade. } \\
\text {-Assiduidade. } \\
\text {-Responsabilidade ética. } \\
\text {-Participação significativa. } \\
\text {-Paciência. } \\
\text {-Automotivação. } \\
\text {-Ser generoso para } \\
\text { compartilhar } \\
\text { conhecimentos com o seu } \\
\text { grupo e interessado em } \\
\text { aprender com o grupo. } \\
\text {-Ter atitude e vontade de } \\
\text { colocar as suas ideias de } \\
\text { forma construtiva, } \\
\text { articulado e cauteloso. } \\
\text {-Ter preocupação em } \\
\text { alcançar os objetivos } \\
\text { individuais e coletivos, de } \\
\text { forma flexível e aberta às } \\
\text { sugestões e críticas } \\
\text { construtivas. } \\
\text {-Ter motivação e vontade } \\
\text { de participar de forma } \\
\text { ativa, aberto e engajado em }\end{array}$ \\
\hline
\end{tabular}




\begin{tabular}{|c|c|c|c|}
\hline & & $\begin{array}{l}\text {-Habilidade de criar estratégias para } \\
\text { ganhar maior produtividade e } \\
\text { entrosamento entre os membros da } \\
\text { equipe nesse momento de } \\
\text { distanciamento social. } \\
\text {-Colaboração no compartilhamento } \\
\text { de conteúdos. }\end{array}$ & $\begin{array}{l}\text { diferentes atividades } \\
\text { propostas. } \\
\text {-Ter atitude e vontade de } \\
\text { colocar as suas ideias de } \\
\text { forma construtiva, } \\
\text { articulado e cauteloso. } \\
\text {-Estar aberto para estudar e } \\
\text { aprender nessa nova } \\
\text { modalidade de ensino. }\end{array}$ \\
\hline $\begin{array}{l}\text { Produção de } \\
\text { material digital }\end{array}$ & $\begin{array}{l}\text {-Conhecer } \\
\text { recursos de } \\
\text { tecnologia } \\
\text { capazes de } \\
\text { permitir a } \\
\text { construção e } \\
\text { apresentação do } \\
\text { mapa } \\
\text { conceitual. } \\
\text {-Conhecer } \\
\text { ferramentas de } \\
\text { busca de } \\
\text { referencial } \\
\text { teórico } \\
\text { confiáveis. } \\
\text {-Conhecimento } \\
\text { sobre } \\
\text { apresentações } \\
\text { em PowerPoint } \\
\text { ou Google } \\
\text { Slides e } \\
\text { Microsoft Word. } \\
\text {-Busca de } \\
\text { informação. } \\
\text {-Proteção de } \\
\text { dados pessoais. } \\
\text {-Bibliotecas } \\
\text { virtuais } \\
\text { disponíveis. } \\
\text {-Conhecer os } \\
\text { diferentes } \\
\text { bancos de } \\
\text { dados. } \\
\text {-Saber (ter } \\
\text { conhecimento) } \\
\text { para produzir } \\
\text { conteúdos. } \\
\text {-Avaliar as } \\
\text { melhores mídias } \\
\text { para produzir } \\
\text { conteúdos } \\
\text { específicos. } \\
\text {-Ter } \\
\text { familiaridade } \\
\text { com alguns } \\
\text { softwares online } \\
\text { de análise e } \\
\text { geração de } \\
\text { gráficos. } \\
\text {-Programação. }\end{array}$ & $\begin{array}{l}\text {-Domínio básico de editor de texto } \\
\text { (exemplo Word). } \\
\text {-Domínio básico de ferramentas de } \\
\text { busca. } \\
\text {-Saber utilizar ferramentas e filtros de } \\
\text { busca. } \\
\text {-Saber filtrar o fluxo de informação } \\
\text { além da capacidade de construir } \\
\text { conhecimento a partir de } \\
\text { informações. } \\
\text {-Raciocínio lógico. } \\
\text {-Prever e estimar resultados e } \\
\text { desenvolver estratégias de resolução. } \\
\text {-Habilidade de eleger os pontos } \\
\text { principais do conteúdo. } \\
\text {-Habilidade do uso da ferramenta } \\
\text { escolhida para a construção e } \\
\text { apresentação do mapa conceitual. } \\
\text {-Saber utilizar os programas } \\
\text { PowerPoint ou Google Slides e } \\
\text { Microsoft Word para fazer } \\
\text { apresentações orais e para a escrita de } \\
\text { trabalhos acadêmicos. } \\
\text {-Trabalhar em equipe. } \\
\text {-Gerenciamento da informação. } \\
\text {-Comunicação. } \\
\text {-Colaboração. } \\
\text {-Manter-se organizados na situação } \\
\text { de ensino remoto. } \\
\text {-Saber utilizar as tecnologias digitais } \\
\text { para preparar e apresentar o trabalho. } \\
\text {-Saber utilizar os bancos de dados e } \\
\text { como filtrar as informações. } \\
\text {-Produzir conteúdos. } \\
\text {-Buscar a tecnologia adequada para o } \\
\text { desenvolvimento de cada conteúdo } \\
\text { e/ou mídias. } \\
\text {-Avaliar a pertinência das } \\
\text { informações pesquisadas. } \\
\text {-Produzir conteúdo com clareza e } \\
\text { fundamentação teórica. } \\
\text {-Compartilhar o conteúdo produzido. } \\
\text {-Buscar conhecimento em bases de } \\
\text { dados. } \\
\text {-Utilizar os simuladores } \\
\text { online/remotos. } \\
\text { formatos (gráficos, formas de onda, } \\
\text { tabelas). }\end{array}$ & $\begin{array}{l}\text {-Curiosidade. } \\
\text {-Criatividade. } \\
\text {-Interesse. } \\
\text {-Dedicação. } \\
\text {-Perseverança. } \\
\text {-Autonomia. } \\
\text {-Pró-atividade para realizar } \\
\text { atividades remotas. } \\
\text {-Foco. } \\
\text {-Ter uma atitude de } \\
\text { resiliência virtual e de } \\
\text { convivência em rede. } \\
\text {-Proatividade na busca por } \\
\text { fontes de informação e } \\
\text { critérios para obter } \\
\text { informação confiável, de } \\
\text { fonte segura. } \\
\text {-Abertura para resolução } \\
\text { de problemas. } \\
\text {-Vontade de compartilhar e } \\
\text { trocar ideias, informações, } \\
\text { dúvidas. } \\
\text {-Responsabilidade ética. } \\
\text {-Participação significativa. } \\
\text {-Dedicação para fazer } \\
\text { tarefas e pesquisa } \\
\text { independente. } \\
\text {-Paciência. } \\
\text {-Automotivação. } \\
\text {-Ter postura crítica frente a } \\
\text { dados experimentais e de } \\
\text { simulação. } \\
\text {-Ter atitude e vontade de } \\
\text { colocar as suas ideias de } \\
\text { forma construtiva, } \\
\text { articulado e cauteloso. } \\
\text {-Ter preocupação em } \\
\text { alcançar os objetivos } \\
\text { individuais e coletivos, de } \\
\text { forma flexível e aberta às } \\
\text { sugestões e críticas } \\
\text { construtivas. } \\
\text {-Estar aberto para estudar e } \\
\text { aprender nessa nova } \\
\text { modalidade de ensino. }\end{array}$ \\
\hline
\end{tabular}




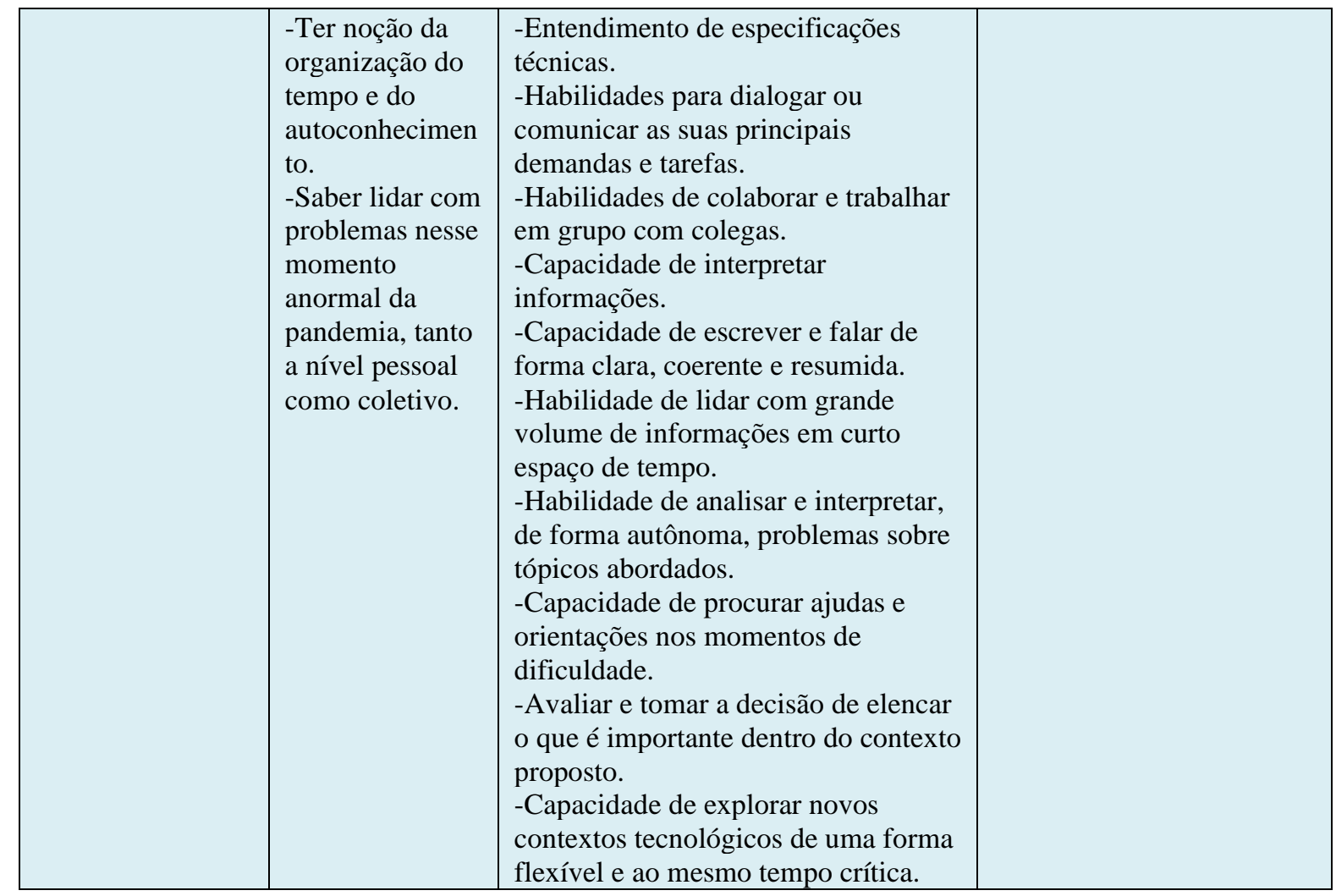

Fonte: Os autores (2021).

Assim, após analisar todas as competências das modalidades de ensino que apareceram, pode-se observar que as competências digitais sobre o uso básico dos recursos tecnológicos são transversais em todas as modalidades de ensino. Essa inferência está relacionada diretamente à realidade brasileira no uso e acesso às tecnologias, que ainda é limitado para uma grande maioria da população, conforme dados apontados pelo IBGE (2019). Além disso, cabe ressaltar que as habilidades elencadas estão vinculadas ao uso crítico e não apenas ao manuseio das TD. Assim, considerando o ERE, "no professor recaem, pois, as funções de motivador, de criador de recursos digitais, de avaliador de aprendizagens e de dinamizador de grupos e interações online" (MOREIRA, HENRIQUES E BARROS, 2020, p.354).

A CD de comunicação, através das videoconferências, é uma das competências transversais em todos os tipos de públicos no ensino remoto, já que "é necessário comunicar-se com regularidade com os estudantes nos diferentes canais de comunicação para que eles sintam a presença do professor e dos seus pares" (MOREIRA, HENRIQUES E BARROS, 2020, p.354). Os autores ainda apontam que "as ferramentas de comunicação, como as webconferências, permitem a comunicação sincrônica com visualização dos utilizadores, o que possibilita uma multiplicidade de aplicações diferenciadas" (MOREIRA, HENRIQUES, BARROS, 2020, p.354). Portanto, as "[...] sessões síncronas são muito úteis, sobretudo, para desenvolver atividades que necessitem de feedback imediato, para promover a participação ativa dos estudantes ou para avaliar a aquisição dos conhecimentos" (MOREIRA, HENRIQUES, BARROS, 2020, p.357). Assim, as competências digitais mapeadas totalizaram 10 e foram separadas para cada tipo de público, conforme apresentado a seguir na Figura 3. 
Figura 3 - Competências Digitais para o Ensino Remoto Emergencial

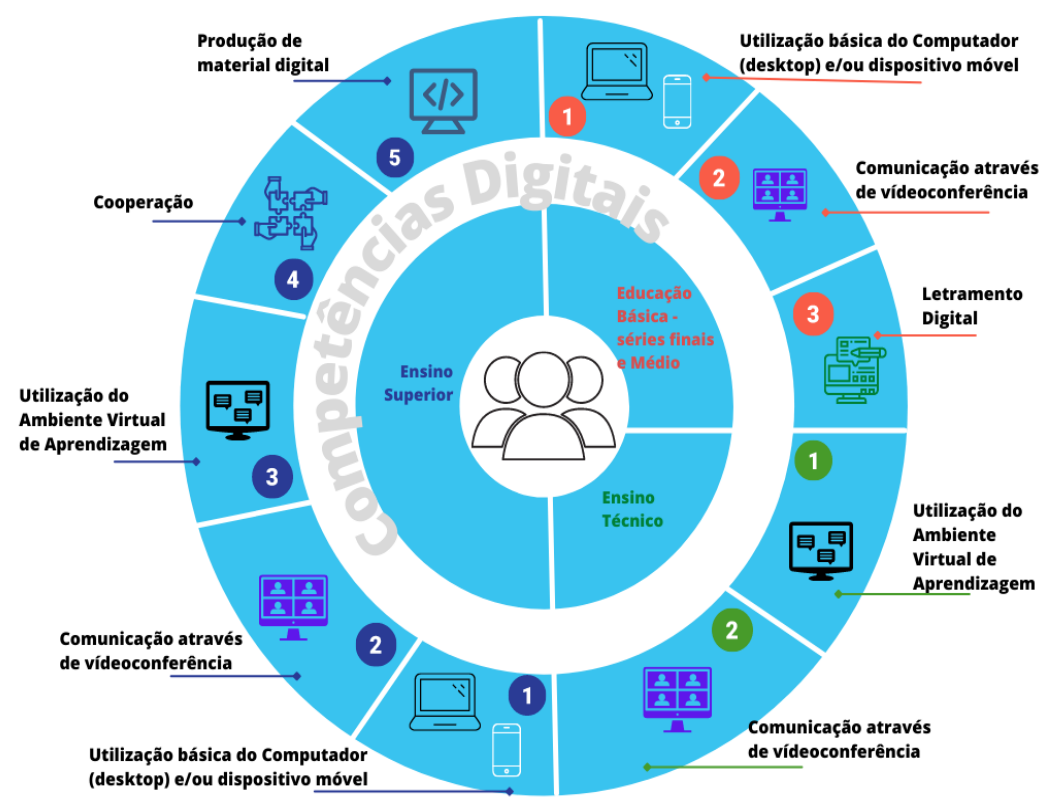

Fonte: Os autores (2021).

Os dados apresentados para a identificação das CD para o ensino remoto possibilitaram analisar a pertinência de mapear e desenvolver estratégias pedagógicas personalizadas para construir as competências em sala de aula. Assim, o desafio está não apenas na identificação das competências digitais necessárias aos alunos de ERE, mas como desenvolver estratégias pedagógicas que permitam a construção delas nas práticas pedagógicas, principalmente que viabilizem as atitudinais a partir das TD.

Os dados denotam a falta de preparo e capacitações, tanto na esfera da graduação como continuada, dos professores em integrar as tecnologias digitais. O maior desafio não é apenas o uso das tecnologias, mas como incluí-las nas práticas pedagógicas de forma a beneficiar os estudantes e não apenas como uma imposição, mas como um recurso que irá fazer a diferença para a formação do sujeito ativo na sociedade. Assim, o próximo passo do professor, além de conhecer sobre as competências, é pensar em ações que são viáveis de desenvolver as CD no ERE, incluindo-as no planejamento.

\section{Considerações Finais}

O presente estudo teve por objetivo identificar as competências digitais necessárias para alunos do ensino remoto emergencial brasileiro e discutir as necessidades na formação continuada dos professores. Assim, participaram da pesquisa 29 professores que atuam com diferentes públicos e modalidade de ensino, no qual estão oferecendo, ou irão ofertar, aulas no Ensino Remoto.

Os dados apresentados denotam uma preocupação dos professores referente ao uso básico das TD e, principalmente, a utilização qualificada e crítica, tornando os alunos não apenas espectadores, mas que estabeleçam relações sociais por voz, vídeo e texto. Assim, ao todo foram mapeadas dez CD para o ERE. No Ensino Fundamental II e Médio foram identificadas três: Utilização básica do computador (desktop) e/ou dispositivo móvel, Letramento Digital e Comunicação através de videoconferência. Já no Ensino Técnico foram 
identificadas duas: Utilização de Ambiente Virtual de Aprendizagem e Comunicação através de videoconferência. Por último, no Ensino Superior, foram identificadas cinco CD: Utilização básica do computador (desktop) e/ou dispositivo móvel, Utilização de Ambiente Virtual de Aprendizagem, Comunicação através de videoconferência - esta está relacionada ao uso seguro de ferramentas de comunicação por vídeo e voz para a participação de aulas remotas, Cooperação e Produção de material digital. Cabe destacar que outras CD para o ERE devem existir e as realidades podem modificar as habilidade e atitudes mapeadas, assim como as estratégias pedagógicas devem ser desenvolvidas de acordo com as especificidades de cada público.

Os desafios para construção das competências digitais no Ensino Remoto são muitas e ainda há muito a investigar. Pode-se observar que os professores ainda estão tendo dificuldade em manusear as tecnologias digitais e principalmente mediar o uso dessas com os alunos. Essa característica aparece em todas as modalidades, desde a Educação Básica até o Ensino Superior, apontando que os professores não tiveram preparo para lidar com as TD. Isso é um reflexo das graduações, desde a de Pedagogia até as licenciaturas, nas quais não se viabilizam disciplinas que possibilitem a discussão e aplicação das tecnologias nas práticas pedagógicas, muito menos em metodologias que podem ser utilizadas para integrar os recursos tecnológicos, tanto na modalidade presencial como a distância. No entanto, pode-se perceber que os professores estão criando ações e buscando cursos de formação para conhecer as tecnologias digitais e quais as melhores estratégias pedagógicas utilizadas com seus alunos.

\section{Referências}

BAO, W. COVID - 19 and online teaching in higher education: A case study of Peking University. Human Behavior and Emerging Technologies, n.2, v.2, p. 113-115, 2020.

BEHAR, Patricia; LONGHI, Magali; MACHADO, Leticia. Domínio tecnológico em EAD. In: BEHAR, Patricia. Competências em EAD. Porto Alegre: Penso, 2013.

BRASIL. Lei $\mathbf{N}^{\mathbf{0}}$ 13.146, de 6 de Julho de 2015. Disponível em:http://www.planalto.gov.br/ccivil_03/_Ato2015-2018/2015/Lei/L13146.htm Acesso em: 17 maio de 2018.

BRASIL. Referenciais de qualidade para educação a distância. Brasília: MEC, 2003. Disponível em: http://portal.mec.gov.br/seed/arquivos/pdf/legislacao/refEaD1.pdf Acesso em: 17 maio de 2018.

BRASIL. Secretaria de Educação Fundamental. Parâmetros curriculares nacionais: terceiro e quarto ciclos do ensino fundamental: introdução aos parâmetros curriculares nacionais / Secretaria de Educação Fundamental. Brasília: MEC/SEF, 1998.

FERRARI, A. Digital competence in practice: an analysis of Frameworks. Sevilla: JRC IPTS, 2012.

GARCIA, T et al. Ensino remoto emergencial: proposta de design para organização das aulas. Natal: SEDIS/UFRN, 2020. Disponível em: https://repositorio.ufrn.br/jspui/bitstream/123456789/29767/1/ENSINO\%20REMOTO\%20E MERGENCIAL_proposta_de_design_organizacao_aulas.pdf 
GILSTER, P. Digital literacy. New York: John Wiley \& Sons, Inc., 1997.

IBGE - Instituto Brasileiro de Estatística. Uso da internet, televisão e celular no Brasil. 2019. Disponível em: https://educa.ibge.gov.br/jovens/materias-especiais/20787-uso-deinternet-televisao-e-celular-no-brasil.html

INSTEFJORD, Elen; MONTHE, Elaine. Educating digitally competent teachers: A study of integration of professional digital competence in teacher education. Teaching and Teacher Education, v. 67, 2017, p.37-45. Disponível em:

https://www.sciencedirect.com/science/article/pii/S0742051X16302888\#tbl2

KÜLLER, José Antonio; RODRIGO, Natália de Fátima. Metodologia de desenvolvimento de competências. Rio de Janeiro: SEMAC, 2013.

LINS, Moniki Andrade Costa. As atividades do portal do professor e o desenvolvimento do letramento digital: uma análise de sugestões de aulas de gêneros digitais. Dissertação [Mestrado], Programa de Pós-Graduação em Letras, Universidade Federal de Viçosa, 2017.

MARINHO-ARAUJO, Claisy; RABELO, Mauro Luiz. Avaliação educacional: a abordagem por competências. Avaliação, v. 20, n. 2, p. 443-466, 2015.

MORAIS, I. et al. Ensino remoto emergencial: orientação básica para a elaboração de plano de aula. Natal: SEDIS/UFRN, 2020. Disponível em:

https://repositorio.ufrn.br/jspui/bitstream/123456789/29766/1/ENSINO\%20REMOTO\%20E MERGENCIAL_orientacoes_basicas_elaboracao_plano_aula.pdf

MOREIRA, José António Marques; HENRIQUES, Susana; BARROS, Daniela. Transitando de um ensino remoto emergencial para uma educação digital em rede, em tempos de pandemia. Dialogia, São Paulo, n. 34, p. 351-364, 2020.

PATRICIO, Maria Raquel; OSORIO, Antonio. Literacia digital intergeracional: desafios e oportunidades para a educação ao longo da vida. EDUSER: revista de educação, v.9, n.1, 2017.

PEDRÓ, Frabcesc. A Tecnologias e a transformação na educação. UNESCO, 2016. Disponível em: https://www.fundacionsantillana.com/PDFs/santillana_LAC150216_Portugues.pdf

PERRENOUD, Philippe. Construir as Competências desde a Escola. Porto Alegre: Artmed Editora, 1999.

PERRENOUD, Philippe. Desenvolver Competências ou Ensinar Saberes? A Escola que Prepara Para a Vida. Porto Alegre: Penso, 2013.

SARAIVA, K. et al. A educação em tempos de COVID-19: ensino remoto e exaustão docente. Práxis Educativa, Ponta Grossa, v. 15, e2016289, p. 1-24, 2020.

SILVA, K K A. Modelo de Competências Digitais em Educação a Distância (EAD) com foco no aluno: MCompDigEAD. 2018. 279 f. TESE (Doutorado) - Universidade Federal do 
Rio Grande do Sul (UFRGS), Programa de Pós-Graduação em Informática na Educação (PPGIE), Porto Alegre, 2018.

VÁZQUEZ-CANO, Esteban; SEVILLANDO, Luisa. Dispositivos digitales móviles en educación: el aprendizaje ubicuo. Madrid: Narcea, 2015.

Recebido em agosto de 2021.

Aprovado em outubro de 2021. 